\title{
Corrigendum: Reference cells and ploidy in the comet assay
}

\author{
Gunnar Brunborg ${ }^{1 *}$, Andrew Collins ${ }^{2}$, Anne Graupner ${ }^{1}$, Kristine B. Gutzkow $^{1}$ and \\ Ann-Karin Olsen ${ }^{1}$
}

${ }^{1}$ Division of Environmental Medicine, Department of Chemicals and Radiation, Norwegian Institute of Public Health, Oslo, Norway, ${ }^{2}$ Department of Nutrition, University of Oslo, Oslo, Norway

Keywords: comet assay, genome size, testicular cells, fish cells, reference cells

\section{A corrigendum on}

\section{OPEN ACCESS}

Edited and reviewed by: David William Galbraith

University of Arizona, USA

${ }^{*}$ Correspondence:

Gunnar Brunborg gunnar.brunborg@fhi.no

Specialty section: This article was submitted to Genomic Assay Technology,

a section of the journal

Frontiers in Genetics

Received: 02 January 2017 Accepted: 10 January 2017 Published: 24 January 2017

Citation: Brunborg G, Collins A, Graupner A, Gutzkow KB and Olsen A-K (2017) Corrigendum: Reference cells and ploidy in the comet assay. Front. Genet. 8:4.

doi: 10.3389/fgene.2017.00004
Reference cells and ploidy in the comet assay by Brunborg, G., Collins, A., Graupner, A., Gutzkow, K. B., and Olsen, A.-K. (2015). Front. Genet. 6:61. doi: 10.3389/fgene.2015.00061

There is an error in the Acknowledgments, as published, as funding from Research Council of Norway, through its Centres of Excellence funding scheme, was omitted. The correct Acknowledgment appears below. The authors apologize for this error, which does not affect the scientific conclusions of the article in any way.

\section{ACKNOWLEDGMENTS}

This work was financed by The European Commission via the project Comet assay and cell array for fast and efficient genotoxicity testing (COMICS; contract no. LSHB-CT-2006-037575), and by the Research Council of Norway through its Centres of Excellence funding scheme, project number 223268/F50 (CERAD, Centre for Environmental Radioactivity).

Conflict of Interest Statement: The authors declare that the research was conducted in the absence of any commercial or financial relationships that could be construed as a potential conflict of interest.

Copyright $\odot 2017$ Brunborg, Collins, Graupner, Gutzkow and Olsen. This is an open-access article distributed under the terms of the Creative Commons Attribution License (CC BY). The use, distribution or reproduction in other forums is permitted, provided the original author(s) or licensor are credited and that the original publication in this journal is cited, in accordance with accepted academic practice. No use, distribution or reproduction is permitted which does not comply with these terms. 